\title{
The turning point in tourist facilities in Sarajevo Bazaar at the end of the 19th and beginning of the 20th century
}

\section{Prekretnica u turističkim objektima na području sarajevske čaršije krajem XIX i početkom XX veka}

\author{
Ahmed Obralića ${ }^{\mathrm{a}}$, Adi Ćorović ${ }^{\mathrm{a}}$ \\ ${ }^{a}$ International University of Sarajevo, Sarajevo, Bosnia and Herzegovina
}

\begin{abstract}
The purpose of the study is to present the buildings and sites in Sarajevo Bazaar that stand for the touristic area during the period of power transition between the Ottoman Empire and the Austro-Hungarian monarchy. Many commercial buildings, shops, warehouses and dairies, as well as larger buildings that were used for trade - "bezistan" were built in the area of the Sarajevo Bazaar in the 15th and 16th centuries. Gazi Husrev-beg played a significant role in the development of Sarajevo together with his properties and goods that are today the endowed properties of a Gazi Husrev-beg Waqf. Sarajevo was a very important and central point of economy and trade in that time. Nowadays tourists are attracted to a city by the natural beauty of its surroundings, architectural and historical monuments, cultural and educational institutions, industry and trade, yet in earlier times the visitors were mainly the traveling merchants coming for trade who used to stay longer, buying and selling various goods. There were many inns including 4 big caravanserais in Sarajevo built for guests from abroad. During the Austro-Hungarian occupation, the first hotels and cafes of the European type were opened in the city. Almost all caravanserais were out of use at the time of power transition, replaced with newly built hotels which brought a new cultural scope to Sarajevo. There is only one caravanserai that survived until now. All the aforementioned confirm the thesis that from today's perspective, the transition of power between the Ottoman Empire and AustroHungarian monarchy was not smooth in terms of architecture and tourism.
\end{abstract}

Key words: touristic facilities, caravanserai, inn, hotel design, tourism.

Sažetak: Cilj ovog istraživanja jeste predstaviti objekte i lokalitete na području sarajevske čaršije koje su predstavljale turističke lokacije u periodu tranzicije vlasti između Osmanskog carstva i Austro-Ugarske monarhije. Na području sarajevske čaršije u XV i XVI veku izgrađeni su brojni objekti komercijalnog karaktera, trgovine, skladišta i daire kao i površinski veće

*Corresponding author

E-mail address: aobralic@ius.edu.ba

This is an open access paper distributed under the license cc) (i) (s) 
zgrade koje su korišćene za trgovinu - „,bezistani“. Gazi Husrev-beg je imao značajnu ulogu u razvoju Sarajeva, te njegovi posedi i dobra čine današnji Gazi-Husrev begov vakuf. Sarajevo je u to doba bio važan centar ekonomije i trgovine. Danas grad privlači turiste zbog prirodnih lepota, arhitektonskih i istorijskih spomenika, kulturnih i obrazovnih institucija, trgovina, dok su u ranija vremena posetioci uglavnom bili putujući trgovci koji su se zadržavali duže, prodavajući i kupujući raznu robu. U Sarajevu je bilo mnogo gostionica, uključujući velike karavan-saraje, izgrađene za goste iz inostranstva. Za vreme austrougarske okupacije u gradu su otvoreni prvi hoteli i kafići evropskog tipa. Gotovo svi karavan-saraji su prestali sa radom $u$ vreme tranzicije vlasti, jer su zamenjeni novoizgrađenim hotelima koji su doneli novu kulturnu dimenziju. Postoji samo jedan karavan-saraj koji je opstao do današnjeg dana. Sve spomenuto potvrđuje tezu da iz današnje perspektive, prelaz vlasti između Osmanskog carstva $i$ Austro-Ugarske monarhije u arhitektonskom i turističkom smislu, nije bio neprimetan.

Ključne riječi: Turistički objekti, karavan-saraji, gostionica, dizajn hotela, turizam.

\section{Introduction}

Gazi Husrev-beg's waqf in Sarajevo was established during the Ottoman period, when Gazi Husrev-beg was the Bosnian ruler (1521-1541). Gazi Husrev-beg dedicated a large part of his life to the development and urbanization of Sarajevo. He invested his great wealth in the construction of significant buildings for various purposes, which turned Sarajevo into a city of an important trade, craft, cultural, educational and military center (Varenjak, 2008). Besides, the Institution of Waqfs has indirectly contributed to the structure of the Sarajevo Bazaar due to the fact it was highly multinational. There were Jews, Orthodox, Catholics, Muslims and others among the tenants in the waqf properties, and they all possessed the same starting contractual rights with the waqf.

In the area of the Sarajevo Bazaar in the $15^{\text {th }}$ and $16^{\text {th }}$ centuries, many commercial buildings such as shops, warehouses and dairas, as well as larger buildings for trade "bezistan" were built. Besides, eight mosques with associated facilities, two large bezistans and four big inns can be seen along the mixed-used streets and shops in which trade caravans loaded with various goods used to arrive. The most important among them are Kolobara-han, the endowment of Isa-beg Ishakovic that was built in 1462; Tašlihan, the endowment of Gazi Husrev-beg (1521-1542); Morića-han built in the late $16^{\text {th }}$ or early $17^{\text {th }}$ century that are today in the possession of Gazi Husrev-beg's $(\mathrm{GHb})$ waqf; and Đulov han which was located within the site of today's Islamic Religious High school. The aforementioned hans were actually caravanserais, which had a large courtyard that could house trading merchants and entire pack horses caravan. Caravanserais were mainly two-floor constructions. The caravanserai used to have only one entrance that would be locked overnight. The yard, with its main purpose of loading and unloading goods, was usually covered with cobblestones and there would be a well or fountain placed in one part of it. Around the courtyard, a wide porch was located on one or more sides and stone warehouses with goods storage were in the background. There was a horse stable on one side of the yard, and at least one staircase led from the ground floor to the first floor, where the guest rooms were located.

At the end of the $15^{\text {th }}$ century, the city consisted of three mahalas (streets), a congregation of Christians and a congregation of Dubrovnik. In the late $16^{\text {th }}$ century, 
The turning point in tourist facilities in Sarajevo Bazaar at the end of the 19th and beginning of the 20th century

Sarajevo had 91 Muslim and two Christian mahalas and a congregation of Jews (Zlatar, 1997). According to data from the Archives of the City of Sarajevo, there were 23 hans and 3 caravanserais located in Sarajevo mahalas in 1659, and, in 1878, there were 50 (larger and smaller) hans in Sarajevo that could accommodate 2640 people and 1262 horses (Kreševljaković, 1991). Today tourists and visitors are attracted to a city by the natural beauty of its surroundings, architectural and historical monuments, cultural and educational institutions, industry and trade, while in earlier times the visitors were mainly the traveling merchants who used to come for trade. They used to stay longer, buying and selling various goods. People who used to travel for business used to stay over in places called "hans". These places were not managed by people who could earn from the stays of guests. "Hans" were charity institutions where guests could stay with their caravans for an affordable price. There were also "misafirhans" for poor people who could not afford to stay. These hans were very important for the economy at that time. During the Austria-Hungary occupation of Bosnia and Herzegovina, the first hotels and cafes of the European type were opened in the city, meanwhile, the first form of mass city transport 'a horse-drawn tram' was introduced together with city lighting due to the start of electricity production(Commission to Preserve National Monuments, 2014). It is important to mentioned that the transition in terms of touristic facilities was not smooth.

Picture 1. Plan of Sarajevo Bazaar before Austro-Hungarian period

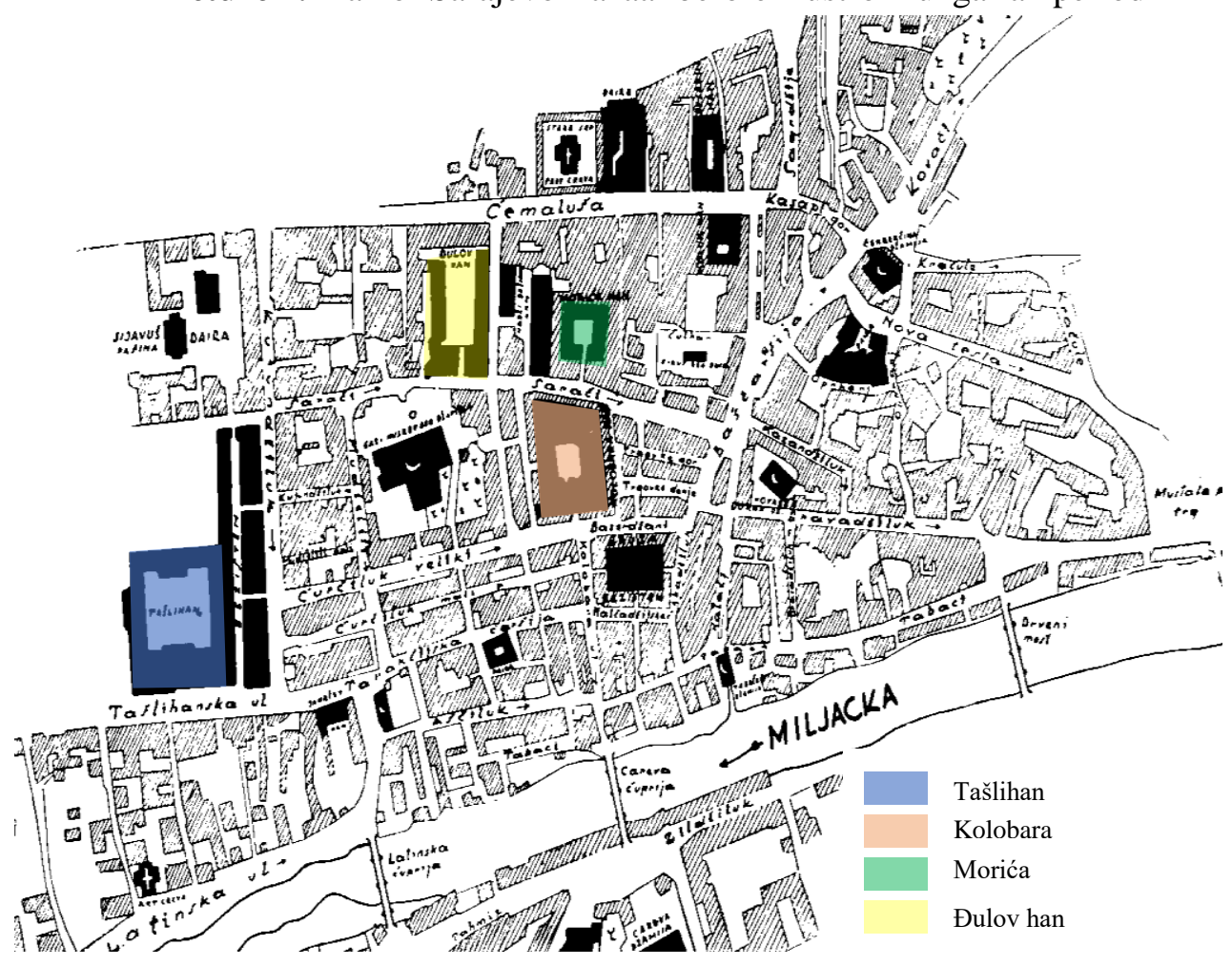

Source: Kreševljaković, H. (1991). Izabrana djela II, Sarajevo 


\section{Kolobara Han - The first Caravanserai in Sarajevo}

The first biggest "han" in Sarajevo was Kolobara han that was built by the founder of Sarajevo, Isa-beg Ishaković, in 1462. There were many shops placed inside of han and its surrounding. Towards the main entrance, there was a bridge, later called "Careva ćuprija". This han stands for the center of the Sarajevo bazaar at that time, playing the significant role during the following four centuries. Kolobara han burned many times during the history: in 1697, 1788, 1831, 1842 and in 1852. Kolobara always had a water supply. Next to the well and the faucet, there was also a fountain. However, they were removed in 1842 due to the installation of new water system.

In the last years of han, some poorer artisans were using the rooms of han as their working place. Thus, han used to function as studios and workshop rather than as regular han, but oversleeping was still possible. The last fire that occurred in 1937, burned and destroyed Kolobara han. In that period, Sarajevo Bazaar lost one of the most important tourist attractions.

Kolobara han was very similar to Morića han regarding its size and architecture, yet the corridor on the upper floor was narrower. Besides, the main difference was that Morića han had only a main and one side entrance, while Kolobara had one main and two side entrances.

\section{3. Đulov Han - Caravanserai}

Đulov han was positioned across the Gazi-Husref beg Mosque. It was the second new Han of Gazi Husre-beg waqf, the first constructed after Tašlihan was Morića Han. Đulov han was named by a reputable tenant, Mustafa-aga Đulović. After the fire in Sarajevo, the palace was built on the same site. The name of the palace was also given by the same tenant. What's more, the building is located in the street "Đulaga street". The façade of the palace towards "Đulaga street" is $60 \mathrm{~m}$, and the length of the north façade is $50 \mathrm{~m}$. The level of the building is set as $\mathrm{G}+2$ and $\mathrm{G}+3$, while the han that existed before was a one-story building.

Picture 2. Đulov han, the location of existence, now Islamic religious high school

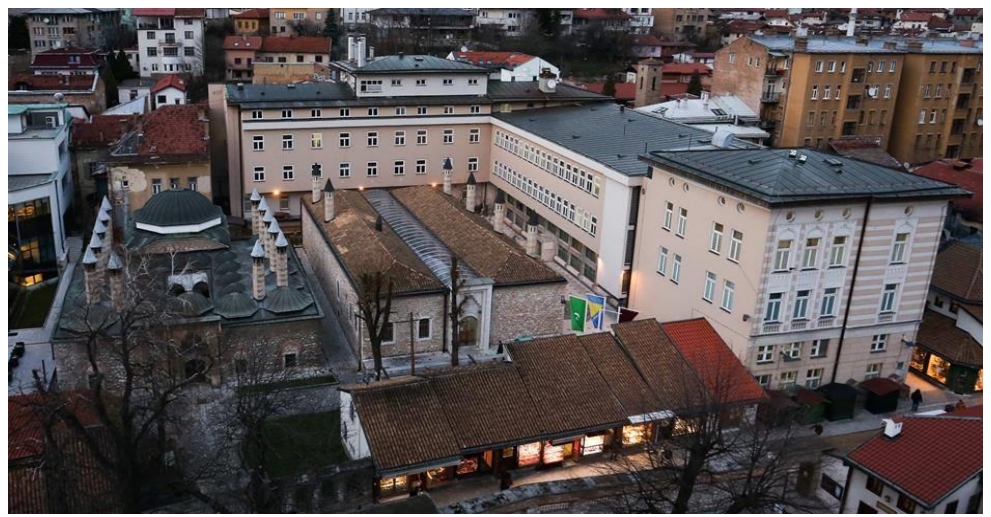

Source: https://muftijstvosarajevsko.ba/ 
The turning point in tourist facilities in Sarajevo Bazaar at the end of the 19th and beginning of the 20th century

This han was different from other hans by its structure. The inner courtyard of this han was closed on three sides. One part of the ground floor was used as a store, and the other part was used as a basement. This han had 3 entrances which were oriented to each street. The ground floor was built from stone and tuff and the upper floor was wooden.

The current facility at this location is Islamic Religious High school (medresa).

\section{Taslihan - Caravanserai}

Sarajevo experienced urban development and general prosperity in the $16^{\text {th }}$ century. Waqfs, feudal class representatives, craft and trade guilds had a significant role in city development due to their investments. In that time, many bazaars, mosques, inns, bridges, schools and caravanserais were built. Taslihan was built between 1540 and 1543 in Sarajevo. Skilled constructors from Dubrovnik were called to work on the construction of han and "bezistan" (trading place) which was next to it. Taslihan was burning for a couple of times, for the first time in 1697, then again in 1831. However, it was completely destroyed by fire in 1879 .

Picture 3. Taslihan, remaining parts of han
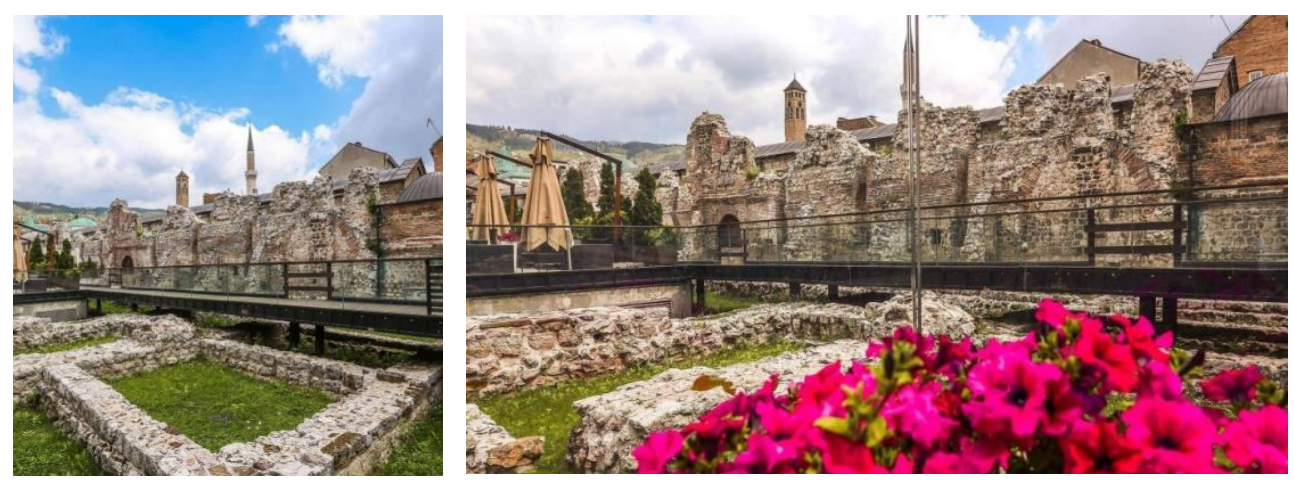

Source: https://sarajevo.travel/en/things-to-do/taslihan/751

Having in mind the centuries-old function, dimensions and significance that Taslihan had, the archaeological research has given significant but still insufficient results so far (Gavrilović, 1998). Tašlihan had an irregular rectangular base and a floor plan solution typical for all one-storey caravanserais. Unlike other inns in which the main purpose of the courtyard was the loading and unloading of goods, in the courtyard of Taslihan were located many shops, which gave it the character of a trading inn. Shops in the southern part of the area were created in the later stages of construction. The "sebilj" (fountain) with several faucets was built in the yard and above it, on the pillars was a small mosque (Truhelka, 1912). Near the main entrance to the inn, two stone staircases were leading to the rooms and hallway upstairs from the courtyard. The rooms were covered with small domes and corridors with a barrel vault. Lead sheet metal was used as a cover (Commission to Preserve National Monuments, 2004). 


\section{Morića Han - Still existing Caravanserai}

Both Tašlihan and Đulov-han were demolished by the great fire that struck Sarajevo in 1879. The fire that occurred in 1937 destroyed Kolobara-han, thus Morića-han remained the only preserved han in Sarajevo. In December 1957, the fire that broke out the bazaar destroyed the roof of the building and large parts of the floor structure. Despite that, its foundation and floors remains were the only preserved parts from the han that belong to the old city architecture from the Ottoman period. The floor and roof construction of Morića-han have been damaged by fire several times throughout history, many times the building has been repaired or rebuilt, but its original condition has always been respected (Redžić, 1983).

Today's name of han dates back to the end of the $18^{\text {th }}$ century. It was named after the tenants who were the members of the famous family Morić from Sarajevo. It used to be called the Second New Han (Han Jedid). It came into the possession of the GHb waqf in the $18^{\text {th }}$ or early $19^{\text {th }}$ century. It belongs to the type of large trading inns, meanwhile, it could accommodate a caravan of 300 people and 70 horses. The tavern that was located in the northern part of Morića-han is probably the oldest Sarajevo tavern and it hosted a large part of the social and political life of the city of Sarajevo. It was a meeting place for craftsmen, merchants and scholars. Guild assemblies were regularly held there. This facility has been the center of craft organizations for more than three hundred years.

Morića-khan played an important role during the Austro-Hungarian occupation. At that time, it was the center of the resistance forces and the so-called People's Committee. Since Morića-han was burned again in 1957, the building was restored during the period from 1971 to 1974 . After restoration, the building was used by the catering company Balkan and it was returned to the ownership of GHb waqf in 1998. Today, Morića-Han stands for a business and tourist center of the GHb vakuf. The management of Waqf tried to rent business premises to the users that would perform activities that fit into the historical environment by their function and which are, at the same time, expressing respect for the new times. There are a restaurant, café and shops on the ground floor. The rooms on the first floor of the building are used as office space - the offices for lawyers and accountants, the headquarters of citizens' associations and cafes. 
The turning point in tourist facilities in Sarajevo Bazaar at the end of the 19th and beginning of the 20th century

Picture 4. South façade of Morića han Picture 5. Inner courtyard of Morića han

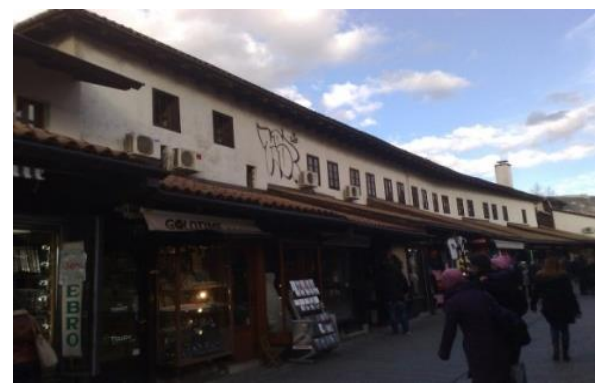

Source:

https://bs.wikipedia.org/wiki/Morića_han\#/media/D atoteka:Morića_han_28022014396.jpg

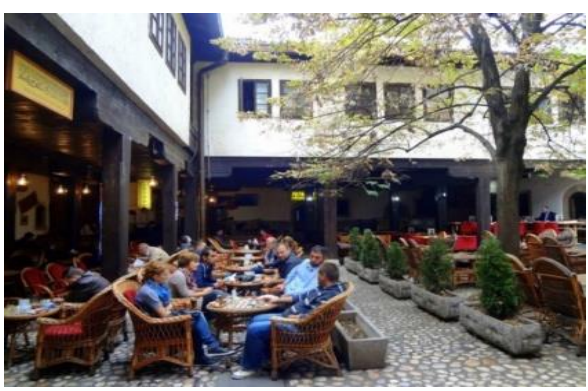

Source: photo by Mina Coric, https://sarajevo.co.ba/znamenitosti/mori ca-han-sarajevo/

Morića-han belongs to the type of large trade inns. The building is a two-story building measuring 44.70x38.40 meters. Concerning the dimensions of the surrounding shops, the dimensions of Morić-han is considered large, due to the facts that the building was developed in regards to width (instead of height) and also by composition and processing of external facades. Yet, its size is not noticeable at all. The building is completely adapted to the scale in which the man/human being is the focus, together with the economy of material and space (Kreševljaković, 1957).

The basement was located in the northern part of the building and housed barns. Due to the large spans, the load-bearing structure was composed of horizontal longitudinally placed wooden beams and a large number of oak pillars (Redžić, 1983).

Picture 6. Inner courtyard
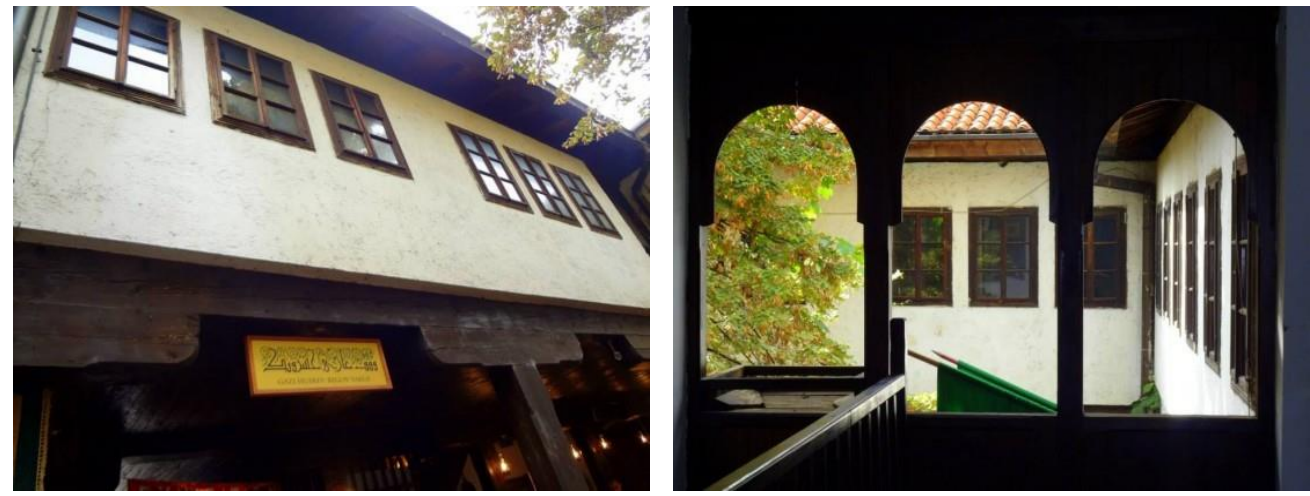

Source: Photos by Mina Coric, https://sarajevo.co.ba/znamenitosti/morica-han-sarajevo/

The central courtyard has a trapezoidal base measuring $27.00 \times 20.50$ meters. The courtyard is located in the center of the inn composition. The yard is accessed through a door which were 2.20 meters wide and located on the south side of the building. The yard is underlined bellow the first floor which is supported by a structure made of wooden oak beams and a large number of oak pillars. In this way, a porch under which horses were loaded and where goods used to be unpacking and packing was formed. 
The yard was paved with cobblestones (Commission to Preserve National Monuments, 2019). Various types of goods were stored in warehouses. Due to the big danger of fire, solid materials were used for warehouses and wall thickness was more than $70 \mathrm{~cm}$. This strong construction on the ground floor was also helpful in carrying the upper floor and roof. Oak beams formed the ceiling of the ground floor coated with an insulating layer in the form of lime and dried horse manure.

Picture 7. Plan of ground floor and plan of first floor
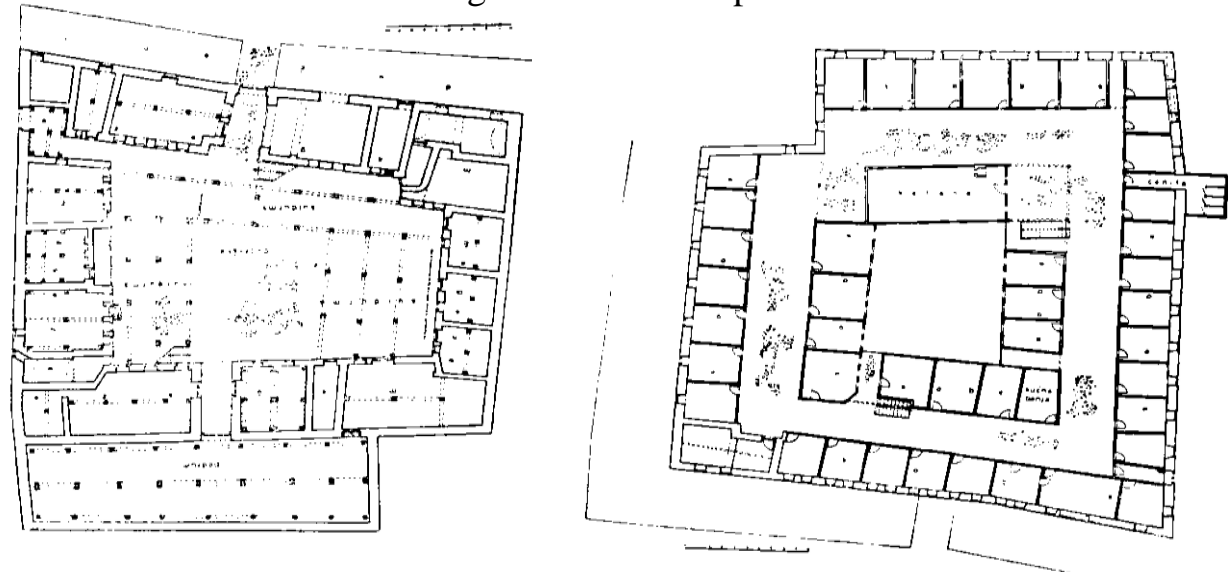

Source: Kreševljaković, H. (1991). Izabrana djela II, Sarajevo

The accommodation space and the other facilities for quests were located on the first floor. In the middle of the first floor, there was a corridor with a width of 4 to 5,2 meters and rooms for guests were on the both sides. There were 40 rooms, and their dimensions was $4 \times 3.5$ meters. There was a public toilet on the eastern part of the building. The majority of rooms were orientated outward, while some of the rooms were orientated to the inner courtyard (Commission to Preserve National Monuments, 2019). The thickness of outer walls was $70 \mathrm{~cm}$ while the thickness of partition walls was $20 \mathrm{~cm}$. Some of the walls were built of adobe and other walls were wooden. The first floor could be reached by two wooden stairs which were $1.8 \mathrm{~m}$ wide. There was also a place for ablution in the courtyard. The corridor had no ceiling, thus the roof construction was visible. Such design provided the light (from the windows on the roof) and enabled the lifting of smoke that was coming from the stoves. The building has had its own special water supply and fountain since ancient times, and a well next to it.

\section{First modern hotels in Sarajevo}

With the establishment of the Austro-Hungarian government in the area of the city of Sarajevo, major economic, social and cultural changes took place. The architecture and urbanism of Sarajevo were radically affected. The Austro-Hungarian period represented a very intense period of construction not only of the Sarajevo Bazaar, but of the entire city. In less than four decades, the government managed to change the physiognomy of the city and to introduce new cultural customs that brought Sarajevo closer to European scope of urban life. The first hotels and cafes of the European type were opened in the city, meanwhile, the first form of mass city transport 'a horse- 
The turning point in tourist facilities in Sarajevo Bazaar at the end of the 19th and beginning of the 20th century

drawn tram' was introduced together with city lighting due to the start of electricity production (Commission to Preserve National Monuments, 2014). Among the first buildings which were used as hotels in Sarajevo Bazaar there were Hotel Europe, Hotel Central, Hotel Grand and Hotel Stari Grad. During the time, many residential buildings were converted to hotels, such as Hotel Zagreb, in the contrary, hotel Grand was used as a hotel only for one year after its construction was completed and later it was converted into a residential building. Besides, many other hotels were constructed in this period but they were not located in the area of Sarajevo Bazaar.

\section{Hotel Europe}

Hotel Europa was the first hotel which was representing the modern era in Bosnia and Herzegovina. It was an investment of wealthy merchant Gligorije Jeftanović. The architect of this project was Karel Paržik and it was located next to Tašlihan that burned in August, 1879. The new hotel Europa was opened in 1882. It was opened only 4 years after the occupation of Austria-Hungary, with the main goal to impose a new cultural model. Since this was the first building of its kind in Sarajevo, the hotel became a focus of the tourism industry and hospitality. The focus was also on additional facilities inside of the hotel, such as "Bečka kafana" inn, Golden restaurant and night club. The facilities were used not just for hotel guestsbut also for local citizens. Additionally, to already existing buildings, the west wing of the hotel was built in the style of contemporary architecture after World War II (Kantonalni zavod za zaštitu kulturno-historijskog i prirodnog naslijeđa Sarajeva, 2018).

Picture 8. Hotel „Evropa“ in past Picture 9. Hotel „Europe“ after restoration

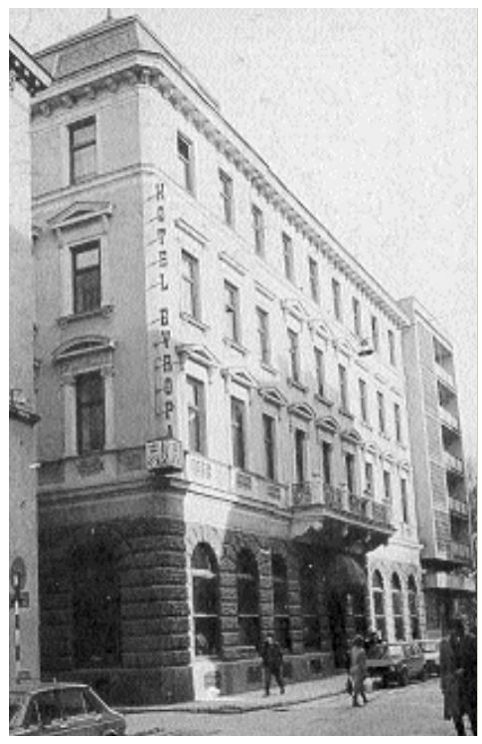

Source: www.spomenici-sa.ba

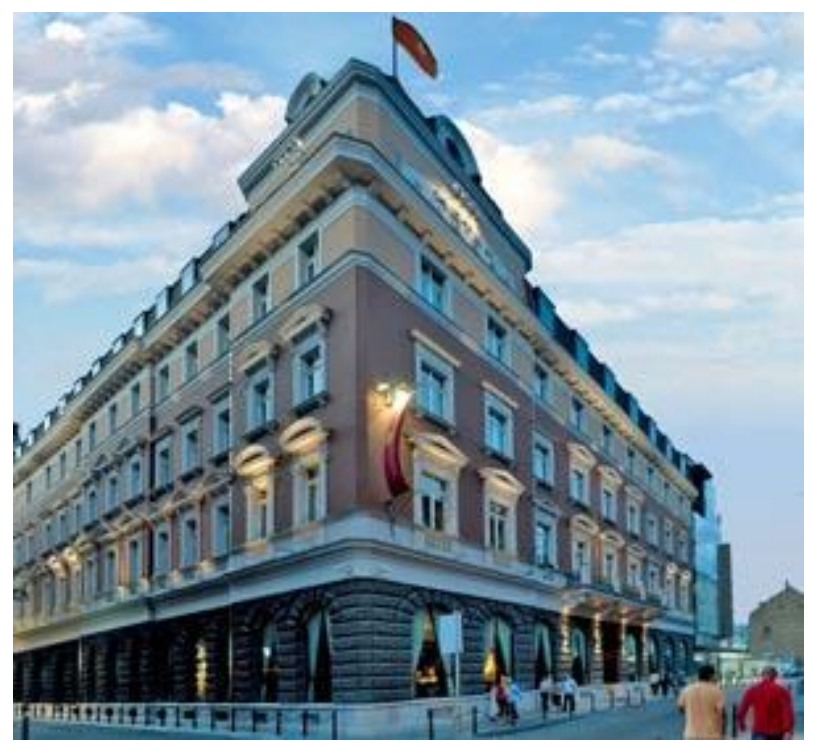

Source: Photo by Amer Kapetanović

Hotel Europa was destroyed during the war 1992-1995 but restored in 2007. It has 125 rooms, 10 suites, 4 presidential suites, spaces for spa, fitness, swimming pool, etc. 


\section{Hotel Central}

Hotel Central was built in the place of Ajas-beg mosque. The mosque was built by the Bosnian governor Ajas-beg in 1474 on the corner of Ćumurija and Franje Josipa streets. Ajas-pasha's mosque was burned down at the time when Eugene of Savoy burned Sarajevo in 1697. It was soon rebuilt, however, it was destroyed again in the fire that broke out in 1879. After that, it was not renovated but Waqf decided to build the hotel "Ajas-pasha's court" in that place at his own expense (Islamska zajednica u Bosni i Hercegovini, 2014).

Picture 10. Hotel Central before the war

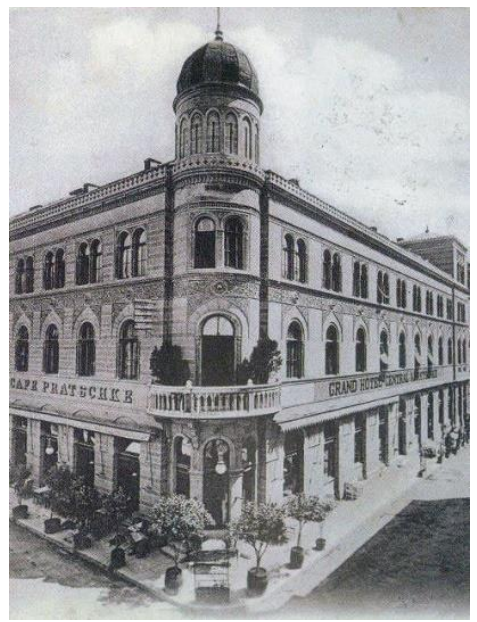

Source: radiosarajevo.ba
Picture 11. Hotel Central after restoration

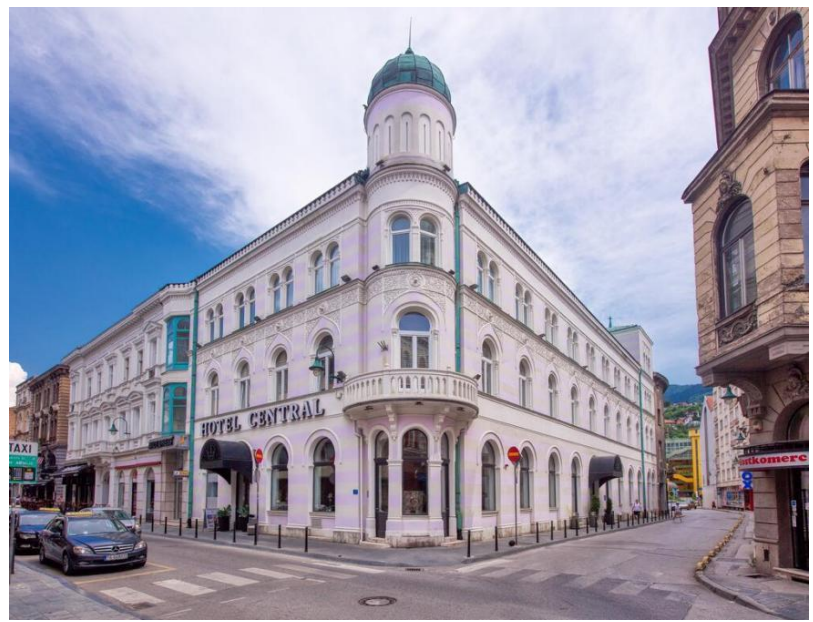

Source: hotelcentral.ba

The project for the hotel was done by architect Josip Vancaš and it was opened in 1889. This hotel was destroyed in the war 1992-1995 but, later, it was renovated and brought capacity to service. After the renovation, some of contemporary facilities were added to the hotel, such as a spa, 25 meters long swimming pool, etc. The hotel has 15 high luxury rooms.

\section{Hotel „Stari Grad“"}

The historical complex of „Stari Grad“ hotel is located in the center of Sarajevo at the intersection of Mula Mustafa Bašeskije and Prote Bakovića streets. It was built by architect Josip Vancas in 1909, during the Austro-Hungarian period. Josip Vancas was the signatories of the project while drawings were done by architect Josip Pospisil (Krzović, 2004). This is a hotel that was built in „Bosnian Style“.

At the beginning of the 20th century, this hotel was one of the most luxurious hotels in Sarajevo with comfort which was following the European level (Ćorović \& Obralić, 2021). The hotel was named after Gazi Husref Beg's knighthood - Gazi hotel (Vatrenjak, 2005). The hotel was built in the place of a former waqf building, which functioned as a lodging house which was later burned down in a fire in 1908. The existing lodging house (han) was founded at the beginning of the $18^{\text {th }}$ century and was 
The turning point in tourist facilities in Sarajevo Bazaar at the end of the 19th and beginning of the 20th century

known as the Kolluk han. It was a private property of Sheikh Haji Idriz who sold it to Gazi Husref Beg's waqf in 1778. The lodging house was a one-story building before the fire. Towards Čemaluša (today's Mula Mustafa Bašeskije Street), there were shops on the ground floor, also there were lounges and a cafe with a coffee pot on the first floor. There was a stone fountain located on the north façade at the right of the entrance. at. On the south side, there was a stable for passenger horses. The lodginghouse had a capacity of 20 rooms and the same number of places for horses (Bejtić, 1974).

During the first half of the $20^{\text {th }}$ century, the eastern block in the new building was used as a hotel whose rooms were equipped with washbasins. The sanitary area with the toilet and shower zone were separated. The east wing of the ground floor was used as a pharmacy until 1965 and the west wing, where the restaurant is located today, served as a hotel restaurant. There was a reception in the business area, between today's restaurant and the passage, which was directly connected with the restaurant.

The hotel was nationalized in 1946. Since then, until the last war in BiH, it was used by publicly-owned catering and hotel companies. In the same year, the hotel changed its name from the hotel "Gazi" to the hotel "Stari Grad". During the second half of the $20^{\text {th }}$ century, the hotel "Stari Grad" was registered as a C category hotel and it did not enjoy a great reputation. In the middle of the $20^{\text {th }}$ century, minor changes were adopted to the building (Bejtić, 1974). During the entire second half of the $20^{\text {th }}$ century, there was a covered summer garden of the hotel on the south side of the inner courtyard, on the site of today's warehouse. On the upper floors, there were hotel rooms equipped with a sink, as well as a separate area with a toilet and bathroom. In 1993, during the war in $\mathrm{BiH}$, the building was damaged. In 2003, the building was returned under the management of the original owner, Gazi Husrev-beg's waqf, that repaired the damaged roof and changed the purpose of the building. There were no preconditions for the adaptation of the building into a modern hotel. Primarily, this refers to the impossibility of creating a parking lot, insufficient accommodation capacity, as well as the potentially high costs of adaptation.

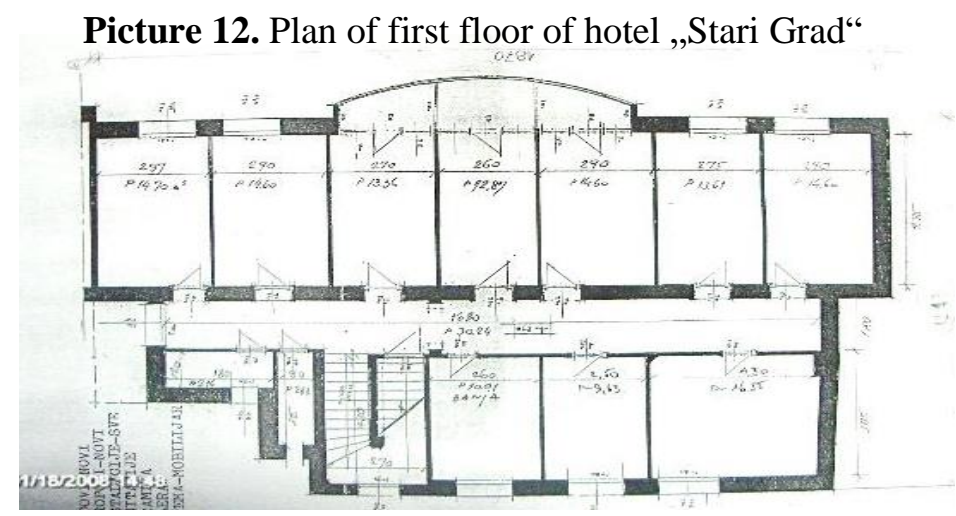

Source: Vatrenjak, M. (2005). Gazi Husrev-begov vakuf. Islamska zajednica u BiH. Sarajevo. 
The cornered building was a two storey, which was built on a plot of an irregular shape with overall dimensions of $24.9 \mathrm{~m} \times 20.33 \mathrm{~m}$. The highest point of the building is $13.65 \mathrm{~m}$. On the north side, there are 7 rooms, $4.95 \mathrm{~m}$ long, with a width from $2.60 \mathrm{~m}$ to $2.97 \mathrm{~m}$. The three central rooms towards M. M. Bašeskije Street are connected by a semi-elliptical protrusion which is $7.60 \mathrm{~m}$ long and $1.50 \mathrm{~m}$ wide at the widest. The rooms are connected to the doxa door with an overhead light with overall dimensions of $85 \mathrm{~cm} \times 280 \mathrm{~cm}$. In the central part, a semi-elliptical protrusion extends through the first and second floors. The protrusion has a central five-leaf window and one side three-leaf window on each floor. The upper floor with the protrusion in wood and glass resembles traditional houses (Kurto, 1997).

\section{Image 13. Hotel „Stari Grad““}
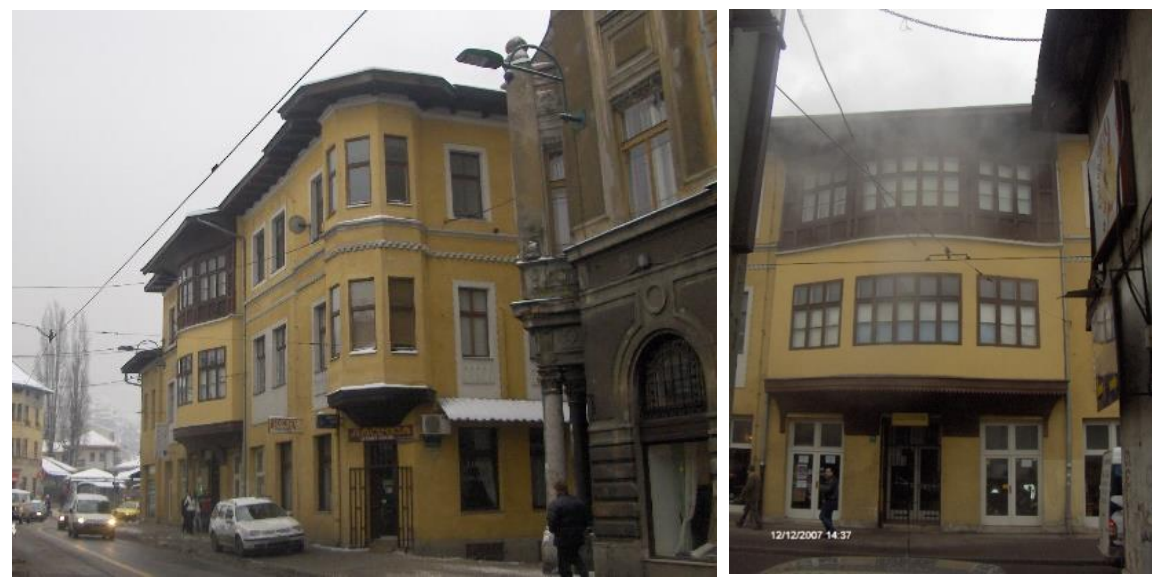

Source: Commission to Preserve National Monuments

The cornered building was a two storey, which was built on a plot of an irregular shape with overall dimensions of $24.9 \mathrm{~m} \times 20.33 \mathrm{~m}$. The highest point of the building is $13.65 \mathrm{~m}$. On the north side, there are 7 rooms, $4.95 \mathrm{~m}$ long, with a width from $2.60 \mathrm{~m}$ to $2.97 \mathrm{~m}$. The three central rooms towards M. M. Bašeskije Street are connected by a semi-elliptical protrusion which is $7.60 \mathrm{~m}$ long and $1.50 \mathrm{~m}$ wide at the widest. The rooms are connected to the doxa door with an overhead light with overall dimensions of $85 \mathrm{~cm} \times 280 \mathrm{~cm}$. In the central part, a semi-elliptical protrusion extends through the first and second floors. The protrusion has a central five-leaf window and one side three-leaf window on each floor. The upper floor with the protrusion in wood and glass resembles traditional houses (Kurto, 1997).

\section{Conclusion}

During the Ottoman Empire in Bosnia and Herzegovina, the touristic facilities were shaped based on the purpose of visitors and travellers of that time. In that period, the touristic facilities were part of waqfs (foundations that served society) and facilities were placed in service of economy and development as well. Therefore, the accommodation in such facilities was not expensive. This fact contributed to the very fast development of Sarajevo and Sarajevo Bazaar at that time. Since the travellers 
The turning point in tourist facilities in Sarajevo Bazaar at the end of the 19th and beginning of the 20th century

visited Sarajevo with the purpose of trade, the touristic facilities were also designed for a trader. With places to stay, storage for goods, places for horses and caravans. Since traveling for trade was not a usual form of tourism that is familiar nowadays, it is obvious that caravanserais in Sarajevo were the forerunner of tourism at that time.

Together with the Austro-Hungarian monarchy, the first hotels and first cafés with European style were designed. During the Austro-Hungarian occupation, citizens of Sarajevo kept their past lifestyle. The resistance to development was not observed. There was a general intention for harmonization of European values and Bosnian reality or for combining the best experiences of two different worlds - Islam and Christianity (Kurto, 1997).

All the aforementioned confirm the thesis that from today's perspective and in terms of architecture and tourism, the transition of power between the Ottoman Empire and Austro-Hungarian monarchy was full of tension. Which was, constructive and useful after all.

\section{References}

Bejtić, A. (1974). Mali urbanizam Sarajeva, Hotel Stari Grad. „Oslobođenje“. Sarajevo.

Commission to Preserve National Monuments of Bosnia and Herzegovina (2019). The Decision to designate the Morić-han building in Sarajevo as a National Monument of Bosnia and Herzegovina. Sarajevo.

Commission to Preserve National Monuments of Bosnia and Herzegovina (2004). The Decision to designate the Taslihan in Sarajevo as a National Monument of Bosnia and Herzegovina. Sarajevo.

Commission to Preserve National Monuments of Bosnia and Herzegovina (2014). The Decision to designate the Saraejvo Bazaar as a National Monument of Bosnia and Herzegovina. Sarajevo

Ćorović A., \& Obralić. A. (2021). Razvoj graditeljske misli u Bosni i Hercegovini tokom prve polovine XX vijeka. Dobra knjiga.

Destination Sarajevo. (n.d.). Taslihan. [Photography]. https://sarajevo.travel/en/things-to-do/taslihan/751

Gavrilović, M. (1998). Izvještaj o rezultatima terenskih arheoloških istraživanja na lokalitetu Tašlihan.

Hotel Central. (n.d.). Hotel Central after restoration. [Photography]. https://www.hotelcentral.ba/

Islamska zajednica u Bosni i Hercegovini (2014). Vakufi sa područja općina Stari Grad i Centar Sarajevo, nekad i sad. Islamska zajednica u Bosni i Hercegovini.

Kantonalni zavod za zaštitu kulturno-historijskog i prirodnog naslijeđa Sarajevo. (n.d.). Hotel Evropa. [Photography]. http://www.spomenici-sa.ba/

Kantonalni zavod za zaštitu kulturno-historijskog i prirodnog naslijeđa Sarajevo (2018). Katalog obnove kulturno-historijskog i prirodnog naslijeđa Sarajeva. Kantonalni zavod za zaštitu kulturno-historijskog i prirodnog naslijeđa Sarajevo.

Kreševljaković, H. (1938). Han Kolobara u Sarajevu. Novi Behar. 
Kreševljaković, H. (1957). Hanovi i karavansaraji. Sarajevo.

Kreševljaković, H. (1991). Izabrana djela II. Sarajevo.

Krzović, I. (2004). Arhitektura Secesije u Bosni i Hercegovini. Kulturno naslijeđe.

Kurto, N. (1997). Sarajevo 1492-1992. Oko.

Mehmedović, A. (2005). Gazi Husrev-beg i njegove zadudžbine. Sarajevo.

Portal Radio Sarajevo. (n.d.). Hotel Central [Photography]. Radiosarajevo.ba. https://radiosarajevo.ba/magazin/muzika-film-lektira/znate-li-kako-je-nekadizgledao-poznati-sarajevski-hotel/225146

Redžić, H. (1983). Studije o islamskoj arhitektonskoj baštini. Sarajevo.

Sarajevo.co.ba. (2013). Morića han. [Photography]. Mina Coric. https://sarajevo.co.ba/znamenitosti/morica-han-sarajevo/

Truhelka, Ć. (1912). Gazi Husrev-beg. Glasnik Zemaljskog Muzeja u Bosni i Hercegovini XXIV.

Vatrenjak, M. (2005). Gazi Husrev-begov vakuf, Islamska zajednica u BiH. Sarajevo.

Vatrenjak, M. (2008). Gazi Husrev-begov vakuf, utjecaj na razvoj društvene zajednice. Sarajevo.

Wikipedia.org. (2014). Morića han. [Photography]. Palapa. https://bs.wikipedia.org/wiki/Morića_han\#/media/Datoteka:Morića_han_2802 2014396

Zlatar, B. (1997). Zlatni period Sarajeva: Prilozi historiji Sarajeva, Institut za historiju.

Received: 10 January, 2021; Revised: 20 February, 2021; Accepted: 1 March, 2021.

Rad je primljen: 10.01.2021. Korigovan: 20.02.2021. Prihvaćen: 01.03.2021. 